Simposium I Jaringan Perguruan Tinggi untuk Pembangunan Infrastruktur Indonesia, 2016

\title{
Struktur Pembiayaan Pembangunan Infrastruktur di Indonesia Penunjang Pertumbuhan Ekonomi
}

\author{
Erika Sefila Putri ${ }^{\mathrm{a} *}$, Wisudanto $^{\mathrm{b}}$ \\ ${ }^{a}$ Universitas Airlangga, Surabaya, Indonesia, erikasevilaputri@gmail.com \\ ${ }^{b}$ Universitas Airlangga, Surabaya, Indonesia,wisudanto@feb.unair.ac.id
}

\begin{abstract}
Salah satu cara untuk meningkatkan pertumbuhan ekonomi suatu negara adalah pembangunan infrastruktur, tetapi pembangunan infrastruktur tanpa ditunjang konsep pembiayaan yang baik akan menghasilkan debt trap bagi negara. Pembangunan infrastruktur perlu memiliki konsep investasi sehingga menghasilkan multiplayer effect yang positif bagi negara dengan mempertimbangkan struktur pembiayaan. Artikel ini bertujuan untuk mengeksplorasi sumber-sumber pembiayaan infrastruktur yang mampu menunjang pertumbuhan ekonomi Indonesia.
\end{abstract}

Keywords:struktur pembiayaan ; multiplayer effect $;$ pembangunan infrastruktur

\section{Latar Belakang}

Infrastruktur berperan penting dalam pertumbuhan ekonomi suatu negara. Infrastruktur meliputi di antaranya jalan, jalan raya, rel kereta api, pelabuhan, dan udara. Infrastruktur yang baik pada energi listrik, bahan bakar minyak (BBM), dan gas juga dibutuhkan untuk mendukung transportasi, industri dan rumah tangga. Fasilitas publik seperti sekolah, rumah sakit, pasar, kantor polisi, serta fasilitas air yang meliputi air bersih, penanganan limbah, DAM, irigasi, dan perngaturan banjir juga sangat dibutuhkan demi mendukung tercapainya kesejahteraan masyarakat suatu negara. Ketersediaan dan peningkatan jaringan telekomunikasi juga akan dapat memenuhi kebutuhan masyarakat terhadap informasi dan komunikasi dengan lebih baik.

Infrastruktur yang layak dan memadai mampu meningkatkan percepatan pembangunan ekonomi dan sosial suatu negara melalui penciptaan efektifitas dan efisiensi yang dihasilkan. Peningkatan pada infrastruktur energi, transportasi dan telekomunikasi dapat secara langsung mengurangi biaya produksi dan waktu yang diperlukan dalam melakukan aktifitas perekonomian, sehingga mampu meningkatkan produktifitas dan kapasitas produksi para pelaku ekonomi suatu negara.

Ketersediaan infrastruktur yang baik mampu mempengaruhi pertumbuhan ekonomi melalui penciptaan hubungan interregional dan memfasilitasi alokasi sumber daya. Hubungan inter-regional yang dicapai dengan peningkatan kualitas pada faktorfaktor mobilitas, informasi dan teknologi, sehingga menciptakan pemerataan pembangunan dan menghasilkan mobilitas tenaga kerja antar daerah menjadi lebih baik. Pemerataan pembangunan akan mendorong terbentuknya investasi baru, lapangan kerja baru dan mampu menciptakan peningkatan pada pendapatan masyarakat. Lebih lanjut, peningkatan pada infrastruktur bidang energi dan transportasi dapat menyalurkan sumber daya alam dari daerah yang memiliki kelebihan sumber daya (SDA) kepada daerah yang kekurangan SDA. Pemerataan sumberdaya infrastruktur mampu mengurangi kemiskinan dan mempengaruhi distribusi pendapatan yaitu ketika terjadi peningkatan produktifitas dan perluasan dana investasi yang dilakukan oleh pelaku perekonomian negara (Serven, 2004).

Menurut data World Economic Forum (WEF) tahun 2015-2016 menyatakan bahwa berdasarkan aspek infrastruktur, Global Competitiveness Index yang dimiliki Indonesia berada pada peringkat 62 di antara 140 negara, dengan peringkat infrastruktur transportasi menempati posisi ke 39 dari 140 negara, sedangkan infrastruktur listrik dan telekomunikasi menemapti posisi ke 80 dari 140 negara. Di kawasan negara Asia, peringkat infrastruktur Indonesia masih tertinggal dibandingkan Hong Kong yang menempati peringkat 1 dan Singapura yang menempati peringkat 2 terbaik dunia. Sedangkan untuk peringkat di kawasan ASEAN, Indonesia menempati peringkat keempat setelah Singapura, Malaysia, Thailand. Hal ini menunjukkan bahwa pembangunan infrastruktur yang memadai di Indoenesia masih kurang kuantitas dan kualitasnya dibandingkan negara-negara Asia lainnya yang tercatat di WEF Report. Hal ini dapat disebabkan oleh faktor-faktor berupa hambatan pada pembiayaan infrastruktur, regulasi pemerintah, serta rancangan dan hasil konstruksi yang tidak sesuai harapan dalam melayani aktifitas masyarakat.

Salah satu komponen penting pada pembangunan infrastruktur negara yang baik didukung oleh pendanaan yang layak dalam tahap perencanaan (planning), proses pembangunan (construction), hingga tahap operasi dan pemeliharaan infrastruktur

\footnotetext{
* Erika Sefila Putri. Tel.: 081233991303

E-mail address: erikasevilaputri@gmail.com
} 
(operational and maintenance). Data Kemenkeu RI menunjukkan bahwa kemampuan pemerintah Indonesia untuk mendanai pembangunan infrastruktur dengan menggunakan dana publik yang berasal dari negara sangat terbatas. Bappenas memperkirakan untuk mencapai target-target pembangunan infrastruktur yang ditetapkan dalam RJPM Nasional tahun 2015-2019 dana yang diperlukan mencapai Rp 5.452 Triliun. Dari keseluruhan dana yang dibutuhkan tersebut, pemerintah pusat dan daerah hanya mampu menyediakan dana sebesar Rp 1.131 Triliun. Hal ini berarti bahwa terdapat selisih pendanaan (financing gap) sebesar Rp 4.321 Triliun yang pemenuhannya dapat dicapai melalui pendanaan alternatif seperti Kerjasama Pemerintah Swasta (Public Private Partnership), dan dengan sumber pendanaan alternative lain berupa dana dari pasar modal, dll.

Konsep struktur pembiayaan meliputi pemilihan instrument keuangan, dan bentuk pembiayaan yang didasarkan pada analisis estimasi arus kas yang dihasilkan baik berupa initial cash outflow yaitu pengeluaran kas untuk membiayai proyek selama dalam proses perencanaan, konstruksi, sampai dengan proyek siap untuk dioperasikan, maupun operational cash inflow yaitu penerimaan kas dari hasil pembangunan proyek infrastruktur dan pengeluaran kas untuk membiayai kegiatan operasi dan pemeliharaan infrastruktur. Struktur pembiayaan yang baik memegang peranan penting dalam menanggulangi risiko konstruksi dan risiko ekonomi yang merupakan 2 risiko utama dalam pembangunan infrastruktur. Hal ini disebabkan karena struktur pembiayaan mempengaruhi total life-cycle cost yang berdampak pada viabilitas keuangan suatu proyek pembangunan infrastruktur. Lebih lanjut, struktur pembiayaan yang baik juga akan mempengaruhi motivasi dan komitmen dari para pihak yang berpartisipasi sehingga mampu mencapai pembangunan infrastruktur yang efektif dan efisien.

Pertimbangan konsep struktur pembiayaan pada proyek pembangunan infrastruktur perlu memperhatikan komponen investasi yang baik dalam pelaksanaannya. Hal ini mengingat bahwa proyek infrastruktur memiliki karakteristik dan keunikan dibandingkan dengan proyek lainnya. Pertimbangan lain yang perlu diperhatikan dalam struktur pembiayaan adalah analisis permasalahan yang mungkin timbul, probabilitas kebangkrutan yang dapat terjadi selama proses pembangunan infrastruktur.

Artikel ini akan memaparkan struktur pembiayaan pembangunan infrastruktur sebagai komponen penunjang pertumbuhan ekonomi Indonesia yang meliputi pembahasan mengenai karakteristik proyek pembangunan infrastruktur, permasalahan dan hambatan yang dihadapi pada proyek pembangunan infrastruktur, serta struktur pembiayaan infrastruktur.

\section{Karakteristik Proyek Pembangunan Infrastruktur}

Proyek pembangunan infrastruktur memiliki karakteristik yang membedakan dari proyek lainnya, yaitu :

\section{- Capital intensity and longevity}

Pembangungan infrastruktur membutuhkan intensitas modal, biaya yang sangat tinggi, likuiditas yang rendah dan membutuhkan pembiayaan jangka panjang, dengan sumber daya yang diinvestasikan oleh investor. Proyek infrastruktur mungkin saja tidak menghasilkan arus kas positif pada tahap awal yang dicirikan dengan tingginya risiko dan biaya selama tahap pre-development dan konstruksi, namun akan cenderung menghasilkan arus kas yang stabil ketika memasuki tahap operational.

\section{- Economies of scale and externalities}

Proyek infrastruktur seringkali mencakup monopoli atas sumber daya alam seperti jalan raya atau persediaan air yang bertujuan untuk meningkatkan skala pendapatan dan menghasilkan manfaat sosial. Pembayaran atas pembiayaan proyek infrastruktur mungkin tidak keseluruhan tertutupi, namun eksternalitas masih bermanfaat bagi perekonomian secara keseluruhan seperti manfaat sosial yang secara fundamental sulit untuk diukur.

\section{- Heterogeneity,complexity, and presence a large number of partie}

Fasilitas infrastruktur cenderung heterogen dan unik dengan susunan regulasi yang kompleks dan terstruktur dalam menjamin distribusi pembayaran dan pembagian risiko yang sesuai untuk menyelaraskan insentif seluruh pihak yang terlibat dalam proyek pembangunan infrastruktur. Keunikan proyek infrastruktur pada pelayanan yang disediakan, struktur, dan kompleksitasnya membuat investasi pada proyek infrastruktur menjadi kurang likuid.

\section{- Opaqueness}

Proyek infrastruktur cenderung kurang transparan di mana informasi yang dibutuhkan oleh investor untuk menilai risiko masih kurang baik, sehingga menciptakan kondisi ketidakpastian. Kurangnya tolak ukur yang jelas dalam pengukuran kinerja investasi juga dipandang oleh banyak investor sebagai penghalang utama dalam berinvestasi pada proyek infrastruktur. kurangnya transparansi dan kecukupan data meningkatkan risiko bagi pihak yang akan terlibat dalam pembiayaan infrastruktur

Asimetri informasi yang besar mungkn terjadi pada proyek infrastruktur beriringan dengan investasi jangka panjang yang dilakukan akan memicu pihak-pihak menjadi bias dalam pengambilan keputusan pada kondisi ex ante dengan kondisi ex post, sehingga dapat menghambat pembiayaan yang optimal. Langkah yang dapat diambil untuk menanggulangi hal ini adalah 
dengan menyediakan profil mengenai risiko dan pendapatan (risk-return) yang sesuai dengan pendapatan yang diharapkan (return expectation) dengan struktur passiva yang digunakan dalam proyek pembangunan infrastruktur.

\section{Permasalahan pada Pembiayaan Infrastruktur}

Mengapa jumlah investasi pada infrastruktur masih kurang memadai meskipun jumlah penawaran atas pembiayaan jangka panjang telah mencukupi ? Pertanyaan ini merupakan hal penting yang menjadi pertimbangan besar para pelaku kebijakan dan pihak yang terlibat dalam proyek pembangunan infrastruktur. Penyelesaian pada permasalahan pada pembiayaan infrastruktur akan dapat memacu pertumbuhan ekonomi jangka panjang menjadi lebih baik. Infrastruktur merupakan input pada aktifitas perekonomian yang besar dan merupakan pemicu penting dalam petumbuhan ekonomi jangka panjang. Penundaan pada realisasi proyek infrastruktur dan proyek yang sudah terealisasi namun menghasilkan kinerja yang tidak sesuai harapan, akan berdampak pada biaya ekonomi dan sosial yang besar. Hal ini justru akan memicu kemunduran pada perekonomian negara.

Dengan demikian, penghalang pada pembiayaan infrastruktur sebenarnya berasal dari bagaimana menyelaraskan penawaran pembiayaan dari para investor dengan proyek yang dianggap layak untuk dibiayai dengan investasi mereka. Pembiayaan dari private investors diperlukan karena berdasarkan data keuangan proyek pembangunan infrastruktur menunjukkan bahwa terdapat financial gap pada dana yang disediakan oleh pemerintah dengan total biaya yang diperlukan untuk proyek pembangunan.

Data Kemenkeu RI menunjukkan bahwa kemampuan pemerintah Indonesia untuk mendanai pembangunan infrastruktur dengan menggunakan dana publik yang berasal dari negara sangat terbatas. Bappenas memperkirakan untuk mencapai targettarget pembangunan infrastruktur yang ditetapkan dalam RJPM Nasional tahun 2015-2019 dana yang diperlukan mencapai Rp 5.452 Triliun. Dari keseluruhan dana yang dibutuhkan tersebut, pemerintah pusat dan daerah hanya mampu menyediakan dana sebesar Rp 1.131 Triliun. Hal ini berarti bahwa terdapat selisih pendanaan (financing gap) sebesar Rp 4.321 Triliun yang pemenuhannya dapat dicapai melalui pendanaan alternatif seperti Kerjasama Pemerintah Swasta (Public Private Partnership), dan dengan sumber pendanaan alternative lain berupa dana dari perbankan, pasar modal, dll.

Peran private investor tidak hanya meliputi penyediaan dana untuk kebutuhan pembiayaan proyek pembangunan infrastruktur, namun juga meliputi peran dalam menjamin bahwa proyek berjalan dengan efisien. Jika kontrak dirancang dengan baik, maka private investors memiliki dorongan untuk mengawasi bahwa proyek pembangunan dijalankan dan dikelola dengan baik. Hal ini disebabkan karena untuk memastikan keamanan atas dana yang mereka investasikan untuk pembiayaan proyek infrastruktur dan mampu menghasilkan expected return yang sesuai. Tantangan bagi perusahaan pelaksana proyek dan sektor public untuk mendesain kontrak yang menyediakan informasi mengenai distribusi pembagian risiko dan pendapatan dengan cara yang dapat meningkatkan insentif private investors untuk menginvestasikan dananya pada proyek pembangunan infrastruktur.

Peran pemerintah dalam proyek pembangunan infrastruktur juga tidak kalah penting, yaitu menyediakan kondisi yang mendukung investasi dengan cara menyusun kerangka kerja atas regulasi yang berkaitan dengan proyek pembangunan infrastruktur. Hal ini bertujuan untuk meningkatkan kepercayaan dan komitmen para investor dalam menginvestasikan dananya dalam jangka panjang meskipun proyek infrastruktur memiliki karakteristik berupa risiko politik dan proyek dengan horizon jangka panjang.

\section{Komponen Struktur Pembiayaan Infrastruktur}

Komponen struktur pembiayaan infrastruktur meliputi 3hal, yaitu bentuk pembiayaan, instrumen pembiayaan, dan biaya modal yang digunakan dalam proyek pembangunan infrastruktur. Bentuk pembiayaan merupakan pemilihan cara pada bagaimana suatu proyek pembangunan infrastruktur akan dijalankan dan dibiayai oleh investor. Bentuk pembiayaan terdiri dari 2 jenis yaitu berupa infrastructure project finance dan corporate balance sheet / corporate finance. Instrumen pembiayaan merupakan alat-alat yang digunakan untuk membiayai suatu proyek pembangunan infrastruktur. Secara umum, proyek pembangunan infrastruktur dibiayai dengan menggunakan instrumen berupa equity dan debt. Biaya modal merupakan perhitungan atas biaya yang harus dikeluarkan oleh pelaksana proyek pembangunan infrastruktur berdasarkan sumber dana yang dipakai yaitu hutang dan ekuitas. 


\subsection{Bentuk Pembiayaan}

Bentuk pembiayaan meliputi infrastructure project finance dan corporate balance sheet / corporate finance, berikut pemaparannya :

\section{- Corporate Balance Sheet / Corporate Finance}

Bentuk pembiayaan dengan menggunakan corporate balance sheet / corporate financemerupakan bentuk pembiayaan infrastruktur tradisional di mana perusahaan yang bergerak di bidang pembangunan dan operasi infrastruktur menerbitkan saham di pasar, atau meminjam dana melalui pasar modal untuk membiayai proyeknya. Perusahaan yang menjalankan proyek infrastruktur memiliki portofolio proyek yang terdiversifikasi dengan kinerja dan risiko operasional yang berbeda-beda.Pada corporate balance sheet / corporate finance, aset dari sumber dana dari proyek yang dibiayai akan menjadi bagian dari aset dan sumber dana dari perusahaan pemilik yang dibangun. Instrument pembiayaan yang dapat digunakan pada bentuk pembiayaan corporate balance sheet / corporate financemeliputi corporate bonds, green bonds, subordinated bonds, direct/co-investment lending to infrastructure corporate, syndicated loans, prefereed stocks, listed infrastructure, closed-end fund, direct/coinvestment in infrastructure corporate equity.

\section{- Infrastructure Project Finance}

Bentuk pembiayaan dengan infrastructure project financemerupakan bentuk pembiayaan infrastruktur di mana perusahaan yang akan melaksanakan proyek atau yang berperan sebagai perusahaan sponsor membentuk suatu entitas khusus yang akan menjadi alat untuk melaksanakan proyek yang akan dibangun atau disebut juga sebagai special-purpose-vehicle (SPV) yang dibentuk khusus untuk melaksanakan suatu proyek yang dinamakan sebagai project company yang keberadaannya hanya sepanjang proyeknya masih berjalan. Dengan demikian, pada infrastructure project finance, aset dan sumber dana proyek akan dicatat terpisah dari aset dan sumber dana dari perusahaan sponsornya. Instrumen yang dapat digunakan pada bentuk pembiayaan infrastructure project finance meliputi corporate bonds, green bonds, subordinated bonds, direct/co-investment lending to infrastructure corporate, syndicated loans, subordinated bonds, convertible nonds, preferred stocks, listed infrastructure, closed end funds, direct/co-investment in infrastructure corporate equity.

4.2. Instrumen pada Pembiayaan Infrastruktur

Tabel 1. Instrumen Pembiayaan Infrastruktur

\begin{tabular}{|c|c|c|c|c|}
\hline Kategori Aset & Instrumen & Infrastruktur Proyek & $\begin{array}{l}\text { Neraca Perusahaan / } \\
\text { Pendanaan }\end{array}$ & Komoditas Pasar \\
\hline & Obligasi (Bonds) & $\begin{array}{l}\text { Project Bonds } \\
\text { Municipal,Sub- } \\
\text { Sovereign } \\
\text { Bonds, Green Bonds, } \\
\text { Sukuk }\end{array}$ & $\begin{array}{l}\text { Corporate bonds, } \\
\text { green bonds } \\
\text { Subordinated Bonds }\end{array}$ & $\begin{array}{l}\text { Bond Indices, Bond } \\
\text { Funds }\end{array}$ \\
\hline \multicolumn{5}{|l|}{ Debet } \\
\hline & Pinjaman (loans) & $\begin{array}{l}\text { Direct/Co-Investment } \\
\text { Lending to } \\
\text { Infrastructure Project, } \\
\text { Syndicated Project } \\
\text { Loans }\end{array}$ & $\begin{array}{l}\text { Direct/Co-Investment } \\
\text { Lending to } \\
\text { Infrastructure } \\
\text { Corporate, Syndicated } \\
\text { Loans }\end{array}$ & $\begin{array}{l}\text { Debt Funds, Loan } \\
\text { Indices }\end{array}$ \\
\hline Mixed & Campuran (Hybrid) & $\begin{array}{l}\text { Subordinated } \\
\text { Loans/Bonds, } \\
\text { Mezzanine finance }\end{array}$ & $\begin{array}{l}\text { Subordinated Bonds, } \\
\text { Convertible Bonds, } \\
\text { Preferred Stocks }\end{array}$ & $\begin{array}{l}\text { Mezzanine Debt } \\
\text { Funds, Hybrid Debt } \\
\text { Funds }\end{array}$ \\
\hline \multirow[t]{2}{*}{ Equity } & Listed & YieldCos & $\begin{array}{l}\text { Listed Infrastructure, } \\
\text { Closed-end Funds }\end{array}$ & $\begin{array}{l}\text { Listed Infrastructure } \\
\text { Equity Funds }\end{array}$ \\
\hline & Unlisted & $\begin{array}{l}\text { Direct/Co-investement } \\
\text { in Infrastructure } \\
\text { Project Equity }\end{array}$ & $\begin{array}{l}\text { Direct/Co-investement } \\
\text { in Infrastructure } \\
\text { Corporatet Equity }\end{array}$ & $\begin{array}{l}\text { Unliisted } \\
\text { Infrastructure Equity } \\
\text { Funds }\end{array}$ \\
\hline
\end{tabular}

Instrumen keuangan yang umum digunakan dalam pembiayaan infrastruktur adalah berupa obligasi, pinjaman bank, campuran dari hutang dan ekuitas. Pada obligasi pembiayaan meliputi project bonds, municipal,sub-sovereign bonds, green bonds, sukuk, sedangkan pada pinjaman terdiri atas direct/co-investment lending to infrastructure project, syndicated project loans. Pada instrumen campuran terdiri atas subordinated loans/bonds, mezzanine finance. Ekuitas dapat berupa yieldcos, direct/co-investement in infrastructure project equity. 
Instrument pembiayaan penting untuk dipadankan dengan fase proyek pembangunan yang akan dilaksanakan, karena instrument pembiayaan yang sesuai akan membantu kelancaran pembiayaan dan menghindarkan dari risiko kebangkrutan proyek pembangunan infrastruktur. Secara umum, instrument pembiayaan dengan menggunakan ekuitas digunakan pada fase konstruksi. Sedangkan ketika proyek sudah selesai dibangun, dan sudah dapat dioperasikan fasilitasnya, maka instrument pembiayaan yang tepat untuk membiayai kegiatan operasi dan pemeliharaan (operation and maintenance) adalah dengan menggunakan obligasi.

\subsection{Biaya Modal Pembiayaan Infrastruktur}

Biaya modal (cost of capital) merupakan salah satu tolak ukur untuk menilai apakah keputusan pembelanjaan yang diambil pihak pengelola pembangunan sudah merupakan keputusan yang optimal. Biaya modal juga penting untuk menilai kelayakan dari suatu usulan proyek investasi. Peranan biaya modal dalam menilai kelayakan suatu usulan investasi bergantung pada metode yang digunakan. Pada metode NPV, biaya modal berfungsi sebagai tingkat diskonto (discount rate), sedangkan pada metode IRR biaya modal berfungsi sebagai cut off rate.

Biaya modal merupakan tingkat pendapatan minimum yang disyaratkan pemilik modal. Dari sudut pandang perusahaan yang memperoleh dana, tingkat pendapatan yang disyaratkan tersebut merupakan biaya atas dana yang diperoleh perusahaan. Besar kecilnya biaya modal suatu perusahaan tergantung pada sumber dana yang digunakan perusahaan untuk membiayai investasi, khususnya sumber dana yang bersifat jangka panjang. Biaya modal penting dipertimbangkan khususnya dalam pengambilan keputusan investasi jangka panjang. Biaya modal dari masing-masing jenis sumber dana (komponen biaya modal) tergantung pada jenis sumber dana yang digunakan. Secara garis besar biaya modal dari masing-masing sumber dana dibagi menjadi 2 kelompok yaitu biaya modal yang berasal dari ekuitas, dan biaya modal dari hutang.

- $\quad$ Biaya modal dari ekuitas

Biaya modal ekuitas dapat diartikan sebagai tingkat pendapatan minimum yang harus diperoleh perusahaan atas investasi yang dibelanjai dengan ekuitas. Dengan menggunakan rumus turunan CAPM (Capital Asset Pricing Model) yang menyatakan bahwa pendapatan yang diharapkan (expected return) dari investasi saham ditentukan oleh pendapatan investasi bebas risiko dan premi risiko pasar. Besarnya premi risiko pada pendekatan ini ditentukan oleh besar kecilnya risiko sistematis $(\beta)$ saham.

$$
\mathrm{Ke}=\mathrm{R}_{\mathrm{f}}+\beta_{\mathrm{i}}\left\{\mathrm{E}\left(\mathrm{R}_{\mathrm{m}}\right)-\mathrm{R}_{\mathrm{f}}\right\}
$$

Tabel 2. Beta Perusahaan

\begin{tabular}{llll}
\hline \multicolumn{1}{c}{ Perusahaan } & $\mathbf{2 0 1 3}$ & $\mathbf{2 0 1 4}$ & $\mathbf{2 0 1 5}$ \\
\hline Adhi Karya & 3,194 & 6,37 & 0,593 \\
Pembangunan Perumahan & 2,57 & 2,549 & 0,886 \\
Total Bangun Persada & 2,579 & 4,08 & 1,697 \\
Waskita Karya & 3,332 & 4,417 & 0,944 \\
Wijaya Karya & 2,11 & 3,471 & 1,155
\end{tabular}

Berdasarkan pada perhitungan dan pengamatan terhadap risiko sistematis 5 perusahaan konstruksi terbesar di Indonesia dengan menggunakan perhitungan CAPM, diperoleh rata-rata risiko sistematis sejak 2013-2015 (Tabel 2).Tampak pada Tabel 2 pada tahun 2013 PT Waskita Karya (WK) memiliki risiko sistematis terbesar yaitu sebesar 3,332 disusul PT Adhi Karya (ADHI) sebesar 3,194. Pada tahun 2014 risiko sitematis rata-rata mengalami peningkatan dengan risiko sistematis tertinggi ADHI sebesar 6,37 disusul dengan WK sebesar 4,417, hal ini di karenakan adanya pesta demokrasi di Indonesia sehingga risiko pasar modal di Indonesia mengalami peningkatan. Sedangkan pada tahun 2015 risiko sistematis tertinggi ada pada PT Total Bangun Persada (TOTAL) dengan nilai 1,697 disusul dengan PT Wijaya Karya (WIKA) sebesar 1,155.

Selanjutnya setelah mengetahui risiko sistematis setiap perusahaan dilakukan analisa lebih lanjut tentang Cost of Equity (COE) dengan metode Estimasi (CAPM), diperoleh COE lima perusahaan besar kontruksi seperti terlihat dalam Tabel 3. Pada tahun 2013, tampak dalam table 3 perusahaan WK memiliki COE tertinggi sebesar 12,51\% disusul dengan ADHI sebesar 12,26\%. 
Tabel 3. Cost of Equity

\begin{tabular}{llll}
\hline \multicolumn{1}{c}{ Perusahaan } & $\mathbf{2 0 1 3}$ & $\mathbf{2 0 1 4}$ & $\mathbf{2 0 1 5}$ \\
\hline Adhi Karya & $12,26 \%$ & $12,70 \%$ & $8 \%$ \\
Pembangunan Perumahan & $11,15 \%$ & $9,59 \%$ & $8,24 \%$ \\
Total Bangun Persada & $11,16 \%$ & $10,84 \%$ & $8,90 \%$ \\
Waskita Karya & $12,51 \%$ & $11,11 \%$ & $8,29 \%$ \\
Wijaya Karya & $10,32 \%$ & $10,34 \%$ & $8,46 \%$
\end{tabular}

Biaya modal yang berasal dari ekuitas biasanya lebih tinggi dibandingkan dengan biaya modal yang dihasilkan dari hutang, karena pemegang ekuitas biasanya mensyaratkan tingkat pengembalian (required rate of return) atas ekuitas yang mereka investasikan lebih tinggi dibandingkan dengan suku bunga hutang. Dengan demikikan, tingkat ekuitas yang lebih rendah akan mampu mengurangi biaya suatu proyek pembangunan. Namun, tingkat ekuitas yang lebih rendah menunjukkan semakin tingginya risiko atas hutang. Bank dan institusi keuangan lainnya mungkin tidak berkemauan untuk membiayai sebuah proyek yang tampak tidak layak atau unbankable, atau hal ini mengakibatkan pihak-pihak yang akan mendanai dengan hutang akan meningkatkan tingkat risk premium untuk proyek dengan tingkat ekuitas yang rendah.

- Biaya modal dari hutang

Biaya modal hutang merupakan tingkat keuntungan yang disyaratkan pemberi pinjaman atas investasi perusahaan yang dibelanjai dengan hutang. Biaya modal harus ditanggung perusahaan karena perusahaan menggunakan hutang untuk membelanjai investasinya. Biaya modal hutang dapat dilihat dari nilai kupon obligasi yang dterbitkan perusahaan pelaksana proyek pembangunan.

Tabel 4. Average Cost of Debt Perusahaan

\begin{tabular}{ll}
\hline \multicolumn{1}{c}{ Perusahaan } & $\mathbf{2 0 1 3}$ \\
\hline Adhi Karya & $8,925 \%$ \\
Pembangunan Perumahan & $9,287 \%$ \\
Waskita Karya & $9,25 \%$ \\
Wijaya Karya & $9,55 \%$
\end{tabular}

Berdasarkan data 4 perusahaan konstruksi terbesar di Indonesia, diperoleh data selama 3 tahun sejak 20132015 menunjukkan bahwa rata-rata perusahaan konstruksi terbesar di Indonesia yang menjalankan proyek pembangunan infrastruktur memiliki biaya modal hutang sebesar 8,925\% pada proyek yang dijalankan oleh Adhi Karya, kemudian sebesar 9,28\% pada proyek yang dijalankan oleh Pembangunan Perumahan, dan sebesar 9,25\% pada proyek yang dijalankan oleh Wskita Karya, serta sebesar 9,55\% pada proyek yang dijalankan oleh Wijaya Karya. Artinya selama 3 tahun terakhir, proyek yang dijalankan oleh perusahaan infrastruktur tersebut memiliki pendapatan minimal yang disyaratkan dalam membiayai proyek dengan menggunakan hutang hutang pada rata-rata nilai pendapatan sebesar 9,25\% selama tahun 2013-2015.

Dengan demikian, setelah meninjau nilai cost of capital berupa biaya modal dari ekuitas (cost of equity) dan biaya modal dari hutang (cost of debt) kelima perusahaan konstruksi terbesar Indonesia, hasil yang diperoleh mencerminkan bahwa pada tahun 2011 dan 2012, biaya modal dari ekuitas masih lebih tinggi dibandingkan dengan biaya modal dari hutang, sedangkan pada tahun 2015 terlihat bahwa rata-rata nilai biaya modal dari ekuitas lebih kecil dibandingkan dengan biaya modal dari hutang. Hal ini mengimplikasikan bahwa, pembiayaan yang dapat digunakan untuk membiayai proyek infrastruktur dapat ditingkatkan melalui ekuitas, karena nilai biaya modal dari ekuitas lebih rendah dibandingkan hutang. 


\section{Kesimpulan}

Infrastruktur berperan penting dalam pertumbuhan ekonomi suatu negara. Infrastruktur yang layak dan memadai mampu meningkatkan percepatan pembangunan ekonomi dan sosial suatu negara melalui penciptaan efektifitas dan efisiensi yang dihasilkan. Salah satu komponen penting pada pembangunan infrastruktur negara yang baik didukung oleh pembiayaan yang layak dalam tahap perencanaan (planning), proses pembangunan (construction), hingga tahap operasi dan pemeliharaan infrastruktur (operational and maintenance).Konsep struktur pembiayaan meliputi pemilihan instrument keuangan, dan bentuk pembiayaan yang didasarkan pada analisis estimasi arus kas yang dihasilkan baik berupa initial cash outflow yaitu pengeluaran kas untuk membiayai proyek selama dalam proses perencanaan, konstruksi, sampai dengan proyek siap untuk dioperasikan, maupun operational cash inflow yaitu penerimaan kas dari hasil pembangunan proyek infrastruktur dan pengeluaran kas untuk membiayai kegiatan operasi dan pemeliharaan infrastruktur.

Struktur pembiayaan yang baik memegang peranan penting dalam menanggulangi risiko konstruksi dan risiko ekonomi yang merupakan 2 risiko utama dalam pembangunan infrastruktur. Hal ini disebabkan karena struktur pembiayaan mempengaruhi total life-cycle cost yang berdampak pada viabilitas keuangan suatu proyek pembangunan infrastruktur. Lebih lanjut, struktur pembiayaan yang baik juga akan mempengaruhi motivasi dan komitmen dari para pihak yang berpartisipasi sehingga mampu mencapai pembangunan infrastruktur yang efektif dan efisien. Pertimbangan konsep struktur pembiayaan pada proyek pembangunan infrastruktur perlu memperhatikan komponen investasi yang baik dalam pelaksanaannya. Hal ini mengingat bahwa proyek infrastruktur memiliki karakteristik dan keunikan dibandingkan dengan proyek lainnya.

\section{Referensi}

Use the "Insert Citation" button to add citations to this document.

[1] Ehlers, Torsten , BIS Working Papers Understanding The Challenge for Infrastructure Finance, Monetary and Economic Department Bank for International Settlement. 2014

[2] Croce, Raffaele Della, Infrastructure Financing Instruments and Incentives, OECD., 2015.

[3] Croce, Raffaele Della ; Gatti, Stefano, Financing Infrastructure - International Trends, OECD Journal : Financial Market Trends, 2014, Volume 2014/1

[4] Islami, Iqbal, Project Finance dan Public Private Partnership : Skema Pendanaan Alternatif Proyek Infrastuktur, Kementrian Keuangan, 2015

[5] ] Islami, Iqbal, Perluasan Jenis Proyek Kerjasama Pemerintah dengan Badan Usaha dalam Penyediaan Infrastruktur, Kementrian Keuangan, 2015

[6] Sudana, I Made, 2015, Manajemen Keuangan Perusahaan : Teori dan Praktik, Jakarta : Penerbit Erlangga 